\title{
Rules vs. Discretion in Monetary Policy: From Commodity Money to Unconventional Monetary Policies
}

\author{
Bogdan Badescu ${ }^{1}$ \\ ${ }^{1}$ The Bucharest University of Economic Studies, Bucharest, Romania \\ Correspondence: Bogdan Badescu, The Bucharest University of Economic Studies, Unirii Boulevard, No.47, \\ Block E3A, Floor 3, Ap. 6, Sector 3, 030825, Bucharest, Romania. Tel: 407-2365-6704. E-mail: \\ bogdanbadescu82@yahoo.ro
}

Received: February 5, 2015

Accepted: Feruary 11, 2015

Online Published: March 25, 2015

doi:10.5539/ijef.v7n4p66

URL: http://dx.doi.org/10.5539/ijef.v7n4p66

\begin{abstract}
This paper proposes a review of the rules vs. discretion in monetary policy debate. Research shows that monetary regimes based on one or more rules had drawbacks, mainly due to the inflexibility imposed by these rules. Therefore, guiding monetary policy strictly by a set of rules is not the optimal approach. The late twentieth and early twenty-first centuries were characterized by a relaxation of the regulations in force, which led in 2008 to one of the worst economic crisis. Since the efficiency and correctness of the measures taken by the authorities as a response to the crisis are questionable and also that their long-term effects (especially the redistribution of wealth) and how to exit from them are still unknown, it becomes clear that a purely discretionary approach is not desirable either. Consequently, it should be implemented a more restrictive approach in terms of the discretionary component embedded in the authorities' decision. A starting point might be to increase the transparency regarding, for example, the algorithm by which the central banks set the policy rate or decide to increase the monetary base. In this sense, for central banks managing reserve currencies could be established publicly announced rules that govern the issuance of money and the policy rate. Moreover, such measures must be combined with improving the regulations in force, so that the attention will be also geared towards the microeconomic level, where it is most important to maintain financial stability. Last, but not least, it is important to remember that this stability should come as a result of the improvement of the general welfare, as the architects of the old Bretton Woods system envisioned.
\end{abstract}

Keywords: monetary policy, rules, discretion, quantitative easing, inflation targeting

\section{Introduction}

The crisis from 2008 and, in particular, the measures taken to remove its consequences reignited the discussion related to the necessity of rules governing the economic activity and, in particular, the money issuance. The idea of finding some rules to help to achieve some monetary targets is not new. According to some historians, the presence of this dilemma can be identified since the Roman Empire. Volkart (2007) examined the available data for 25 cities from the period 1352-1562 and concluded that those that managed their own currencies were more effective in ensuring their stability than cities whose currency was provided by a prince. In other words, the existence of rules aimed at maintaining the purchasing power of money is preferable to discretionary policies in this regard. Two centuries later, Smith (1776) noted in the "Wealth of Nations" that the use of paper money, provided their issuance is properly regulated, may "even bring benefits". Ensuring the so-called proper regulation rose controversies. After some, the banks of issue had to adjust their activity as they saw fit, after others there had to be rules imposed. From the last category, the most prominent voice was that of Henry Thornton (1802), who argued that there is no automated method to control the amount of banknotes in circulation. Therefore, this task should be the responsibility of an institution (Bank of England) which was to guide the system based on some macroeconomic considerations. This view made Thornton to be considered the father of modern central banks. He sketched the principles that should guide such bank, among which was the recommendation that the amount of money in circulation should not be decreased but let to fluctuate within certain limits and allowed to increase slightly if the economic activity grew and also that the bank had to act temporarily off limits if there were extraordinary circumstances. After four decades occurred the famous debate between the currency and banking school. The firsts argued that inflation comes from excessive government 
spending, while others explained inflation as a mismatch between the amount of banknotes in circulation and the needs of trade. They wanted banks of issue to adjust the amount of money based on existing demand, so it should have fluctuated not be limited by rules. Laider (2002) analyzed the dispute and showed that it is preferable to have an exchange rate constraint i.e. to keep constant the coverage of the stock of money with precious metal instead of discretion in their issuance. Shortly after this dispute, Bagehot (1873) analyzed what should a central bank do in order to achieve what we call today financial stability. He showed that in times of crisis, the central bank must provide liquidity, or in other words, to sterilize any losses of the reserve asset, by granting substantial loans to eligible banks.

The twentieth century brought the First World War which caused, among other things, a huge inflation. With this occasion, writings such as " $100 \%$ money" by Fischer (1920) and "A tract on monetary reform" by Keynes (1923) gave a new dimension to the discussion related to a managed currency or a currency subject to rules. Commodity money began to lose their importance, as maintaining price stability started to be considered more important than exchange rate stability. This stability implied in Keynes's vision the breaking of all links with gold, while Fischer believed that gold is necessary to be kept as an anchor, only that its stiffness had to be made more flexible. He proposed the monitoring of an index of the purchasing power of gold in relation to other products and its fluctuations should have been offset by redefining the gold content of the currency. For example, a variation of this index by $1 \%$ would mean that the currency has lost $1 \%$ of its purchasing power, so its gold content should be increased by $1 \%$. Otherwise, the operation was reversed. Despite his efforts, Fischer's proposal was not implemented.

Since 1950 and until 1971, the last stage of the existence of commodity money is consumed. The Bretton Woods system, which required signatory countries to keep their exchange rate stable by binding it to gold and set the IMF to help overcome temporary imbalances of payments among members, collapsed in 1971, when US President Nixon suspended the convertibility of the US dollar.

After 1971, fiat money management goes through several stages, starting with exchange rate targeting, monetary targeting, inflation targeting and, finally, the implementation of unconventional monetary policies.

\section{Some Types of Rules, in Chronological Order}

\subsection{Commodity Money}

Their principle of operation involved the possibility to convert one currency into a good at default parity and the monetary policy's objective was to ensure that convertibility was always maintained. The convertibility rule is the first rule limiting monetary expansion, with the hope of containing inflationary pressures coming from the government and not only. As for the relation with the outside, the capital was free to move, so any movement in the balance of payments turned into an increase or a decrease in the number of banknotes in circulation. Commodity money can be considered the most longevous rule that governed money creation, their period ending de facto in the early 1900s, even though full switch to fiat money was made in 1971. The bulk of the period in which such money circulated is called free banking and involved the lack of central banks. The results of my research covering this type of banking showed that commodity money were complemented by other restrictions on the banking activity such as the requirement to hold government securities as collateral for notes issued (USA), the obligation to publish financial data (USA, Chile), the prohibition of accepting land as collateral (Australia and partially in Scotland), capping interest rates (Scotland) etc. Therefore, the rule of convertibility was not sufficient to ensure price stability by itself. Although the general consensus is that inflation under free-banking was lower than the inflation under central banking (Mafi, 2003; Meltzer \& Robinson, 1989), it is important to mention that the price level was stable in the long run, but on short term (annually) it was very volatile, registering variations of $\pm 10-15 \%$ per year (Jastram, 1977; Bernanke, 2012). The problem lied in the existence of fractional reserves without minimum limits stipulated, which caused the amount of money to be practically indefinite. For example, in the Scottish system the gold coverage of banknotes ranged from $20 \%$ at the end of the eighteenth century to 0.5 to $3.2 \%$ at the beginning of the nineteenth century. Therefore, at the same stock of gold, a gold monetary unit could support in circulation an extra 4 to 199 units of paper money.

Also during this period appeared the concept of what we call monetary base due to the observation that the total volume of money in circulation could be controlled through the quantity of the reserve asset. This principle is true today, where the central bank, by controlling the quantity of cash in circulation and commercial bank reserves, influences the evolution of other monetary aggregates.

The first decades of the twentieth century brought a weakening of the role of this kind of money. Increasingly more opinions converged to the idea that for the well-functioning of the system had to be implemented other rules than convertibility. Thus, the role of gold, symbol of commodity money, began to diminish as price stability 
started to be more important than exchange rate stability.

In short, a monetary system based on such money involves three pillars: a fixed exchange rate, because all currencies are defined in gold, the presence of entities that monitor the system (central banks) and free flows of capital.

\subsection{The Bretton Woods Regime}

The Bretton Woods regime was an attempt to combine the classical gold standard regime with the advantages of flexible exchange rates (Bordo, 1993). The problem of the gold standard (as well as of any commodity money) was that prices were volatile and the national economies were vulnerable to the inflows or outflows of gold. Therefore, it was believed that more flexible exchange rates might help national economies to better insulate themselves from foreign shocks. As previously mentioned, price stability started to be more important than exchange rate stability.

The system put the US dollar at its center marking the beginning of US financial dominance. This situation created a paradox that became known in the economic literature as the "Triffin Dilemma", which states that the country whose currency is also the reserve currency must make a trade-off between short term domestic goals and long term international goals. Out of the two, it is quite unlikely that the domestic goals will be discarded, even if the statute of supplier of the reserve currency brings certain benefits. The problem lies in the fact that beyond one point, the reserve currency's price in gold will depart from its official value, usually suffering a depreciation. In this case, the supplier of the reserve currency can either start implementing measures to correct this deficiency or abandon convertibility. In the first case, those measures imply what we call a tightening of the monetary policy, which affects the national economic environment. In the second case, which is what actually happened, the system collapsed.

In terms of performance, judged by inflation and economic growth, the regime ranked well as Meltzer and Robinson (1989) find that the economic growth in this period was the highest compared to previous and post regimes, up to the year 1985. However, it is important to remember that economic growth can be partly justified by the fact that the system overlapped the period of the reconstruction of the economies of the war-torn countries. As for inflation, the regime was on average better than the fiat standard regimes that succeeded it and under the gold standard.

The fall of the Bretton Woods system was caused primarily by the US pursuing an inflationary policy which was in line with its domestic goals but not appropriate with its role as supplier of the reserve currency. In fact, the system evolved in its final years towards a dollar standard, as it was clear that the US did not have the necessary gold to back the dollars issued. In this moment, countries became reluctant to either allowing the US to gain the seigniorage revenues associated with issuing dollars (France), unwillingness to import inflation (Germany) or to accept opportunity costs of holding greater and greater amounts of US dollars (probably almost all countries). This shows that a system dependent of a single reserve currency is not the best choice. Finally, I would like to recall that this regime was presented as one that promotes prosperity, aiming at assuring full employment and rising wages. In this light, one important lesson that can be drawn and applied to today's circumstances is that the general welfare should come first and stability afterwards, as a result.

\subsection{The Taylor Rule}

Taylor's rule (1993) discards the quantitative aspect of monetary targeting and shifts to setting policy rates. In general, the rule implies that the central bank should react to two variables: the gap between current and desired inflation and the gap between actual and potential GDP. In its general form, Taylor's rule can be written as:

$$
i t=i+\pi t+\alpha\left(\pi t-\pi^{*}\right)+\beta\left(y t-y^{*}\right)
$$

where $i t$ is the interest rate in period $\mathrm{t}, i$ is the equilibrium real interest rate, $\pi t$ is the inflation rate, $\pi^{*}$ is the desired rate of inflation and $\left(y t-y^{*}\right)$ is the GDP gap.

The classic form of the rule is:

$$
i t=i+1.5(\pi t-2)+0.5\left(y t-y^{*}\right)+2
$$

The rule is simple and intuitive. Coefficients can be modified so that the importance given to the two variables, inflation and GDP gap can be adjusted. The focus is on inflation and it implies that for a change of $1 \%$ in its value the central bank should adjust the interest rate by $1.5 \%$. Introducing the GDP gap was made because the US central bank has a mandate aimed also at full employment. However, this approach is consistent with an inflation targeting regime, where even if the central bank is not responsible for promoting economic growth, it is not indifferent to the evolution of this variable. 
Regarding the usefulness of this rule, opinions seem to indicate a low utility. For example, Asso et al. (2010) summarize the views of some major central banks. They find that the European Central Bank indicates that the two variables are not usually sufficient to calibrate the monetary policy. Factors like exchange rates, fiscal indicators etc. must also be taken into account. The Bank of Japan shares the same view, but believes that such a rule is still useful for the estimations than can be made using it. A similar approach is found in the case of the Bank of England. King (2001) believes that a flexible inflation targeting regime brings superior results to using simple Taylor-type rules.

Currently there are in use a variety of rules derived from the original rule proposed by Taylor. Their importance appears to be secondary, as no central bank guides itself only by such a rule. The merits of this rule remain the impulses given towards greater transparency and independence of the central bank.

\subsection{Inflation Targeting}

As previously shown, monetary targeting eliminated the lack of response to national conditions implied by exchange rate targeting, but suffered from a lack of correlation between the aggregates and the targeted variables. To correct this, it was passed to the inflation targeting regime. This means that the central bank announces what rate of inflation targets on medium term and then the expected rate is compared with the recorded rate and the monetary policy is adjusted according to the difference between the two.

The definition highlights several positive features of the regime. The first is that it allows the central bank to take into account developments in the national economy, so it can respond, for example, to changes in the velocity of money, thus eliminating the inconvenience discussed at monetary targeting. In addition, setting clear targets increases the central bank's accountability, so on one hand, the public can assess more easily whether the bank has achieved its goal and, on the other, the political pressures to conduct monetary policy in a certain way, usually expansionist, are significantly tempered. The big advantage is that, as noted by Mishkin (1999), such a system shows that the central bank can control inflation rather than support economic growth.

One of the questions that can be asked is why, as long as this regime directly targets inflation and the central bank's mandate is to ensure price stability, the inflation target is not zero? The answer comes from the fact that in extreme situations such as those experienced today, interest rates charged by banks cannot be negative, so the policy rate loses its effectiveness and can no longer give a boost to the economy. Conversely, if a $2 \%$ inflation is allowed, for example, real interest rates become negative, so that the depositors are encouraged to spend rather than save and the investors to borrow and invest, given the low or even negative costs credit. Basically, the option of having negative real interest rates is paid by accepting a very low inflation. Another argument is that methods of calculating the price index are sensitive to non-monetary fluctuations, so pursuing a null variation is impossible.

The proper functioning of this strategy requires the existence of a high degree of independence of the central bank, so that it does not respond favorably to the government's financing needs, either by issuing currency or by reducing interest rates or other mechanisms. Another problem is the trilemma, especially when the central bank is forced to keep the exchange rate stable, as is the case in emerging economies. As long as inflation target coexist with other objectives of the monetary policy and the central bank does not have the means to transmit to the public its priorities and how will act to achieve them in a credible way, there will be a tension between inflation targeting and other objectives.

This regime also enjoys transparency, by publishing inflation reports, by holding press conferences discussing various aspects of inflation, the central bank's objectives etc.

\section{Unconventional Monetary Policies}

As the crisis forced the authorities to lower the policy rates to almost $0 \%$, this instrument was used to the maximum, so other measures were needed to continue the easing of the monetary policy. These came to be known as unconventional monetary policies and I will insist on them in the followings. Although these policies have manifested in many forms, they can fall into three categories, according to Cerna (2014): signalling policies, policies aimed at providing liquidity and asset purchase policies. Because policies aimed at providing liquidity, even under very relaxed conditions, can be treated as part of the role of lender of last resort that the central bank has, I will not insist on them in this paper.

\subsection{Signalling Policies}

Such policies are useful because central banks cannot fully understand how the financial markets work, which is why, at least under special circumstances, they should be transparent in terms of the objectives they pursue and the variables used as benchmarks. If in the past the perception was that the central bank should leave some 
ambiguity about its future intentions, as Greenspan once said "If you understood more than 20 per cent of what I said, it means I didn't express myself well", the crisis has changed this perception and today the major central banks of the world are clear about their objectives and the actions they will take.

In practice, central banks have used these policies to describe how the policy rates will evolve. In other words, these policies aimed at anchoring the public's expectations about the future values of policy rates, exploiting a finding of the economic research, namely that the public's expectations about a particular phenomenon affects its current behaviour and, therefore, the macroeconomic equilibrium.

The best example of a signalling policy is the forward guidance adopted by the US central bank (the Fed). In 2008, the Federal Open Market Committee decided that, due to the poor conditions of the US economy, the policy rates will remain at exceptionally low levels "for a while". Three months later, "for a while" turned into "a longer period of time" and, in 2012, as the US economy still wasn't recovering, the period considerably extended "until the economy shows signs of recovery". In October 2014, the Fed reiterated that the policy rate will be kept at a minimum until it will achieve its objectives of full employment (i.e. the unemployment rate below $6.5 \%$ ) and an annual inflation rate of $2 \%$.

In the European region, the European Central Bank (ECB) has been slower to adopt such a policy. In fact, the first signal sent to the market was in 2012, when Mario Draghi, the ECB President, announced that it will do whatever it takes to save the euro, without giving specific details. Regarding policy rates, the ECB announced in July 2013 that it would keep them low "for a long time", adding in 2014 that even if inflation is approaching the $2 \%$ target, the poor economic prospects will keep the monetary policy in this stance.

A natural question is how effective is such a policy. Given that the objective of any central bank is to control inflation, what will happen when these low interest rates will be below those indicated by the models used in the calibration of the monetary policy, such as, for example, Taylor's rule? Will the central bank waive them or accept a higher inflation? These questions show that it is not clear how useful such policies really are. Furthermore, the implementation of programs aimed at purchasing securities makes the empirical research on its effectiveness even more difficult.

\subsection{Asset Purchase Policies}

These are the most mediatized, since, unlike those above, they involve the direct intervention of the central bank through the acquisition of securities. This policy assumes that the economy is in a "liquidity trap", a situation which is characterized by the fact that interest rates are very low or even zero and fluctuations in the money supply do not affect the price level. Under these conditions, the public is very interested in hoarding cash because his expectations are that a period of deflation will follow, so the purchasing power of money will increase. Consequently, any surplus money created by the central bank will be hoarded instead of being spent.

According to Bowdler and Radia (2012), the transmission mechanism of these policies can be represented as follows:

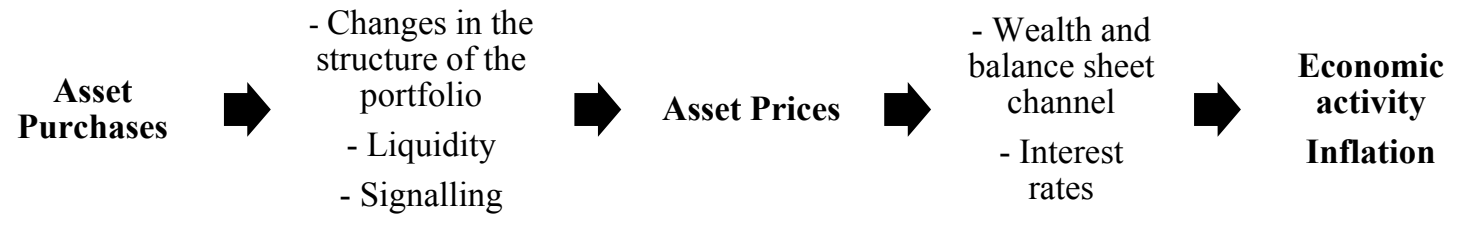

Figure 1. The effects of asset purchases by central banks

In the first phase, the central bank buys assets to inject liquidity into the system. It is important that those assets are not substitutes for money (i.e. they are not highly liquid) because if so, the strategy will not work. Any asset acquisition involves an increase in their price as a result of the rise in the demand. Moreover, in the case of assets generating a fixed income (such as bonds), these purchases, coupled with the commitment to keep policy rates to a minimum, will put pressure on the interest rate demanded by investors, because it eliminates the interest rate risk, for which the latter demand remuneration. The result is that, on one hand, the increase in the price of some assets can make them to be considered too expensive to be bought and, on the other, a decrease in the remuneration of others can make them unattractive. This change in the composition of the available portfolio requires investors to turn to other types of assets, even if they are riskier. In terms of liquidity, it is easy to guess 
that if funding disappears or is very expensive, liquidity injections made by central banks through buying operations help at improving market conditions. Finally, sending a signal relates to the fact that such operations induce the idea the monetary policy will continue to be relaxed in the future.

In the second phase, asset prices would have risen, at least in theory. Consequently, due to their revaluation, there is an increase in the wealth of their owners and, therefore, the possibility that they spend or borrow more. This trend is exacerbated by the fact that, following the acquisitions made by central banks, the risk-free interest rate, which is the base for calculating interest rates at different maturities, decreases, therreby causing a general decrease in the interest rates charged by banks on loans of different types. However, it can be seen that the beneficiaries from these operations will be those who have access to financial markets i.e. companies, households that already hold assets etc. Most of the households and small businesses will not benefit from these programs or, if they do, it will be due to side effects. Therefore, such policies may cause a redistribution of wealth in favour of the wealthy.

Such policies help to enhance the credibility of the fact that the central bank will keep the policy rate at zero as long as necessary. In addition to the impulse given by injecting liquidity into the system, by massively buying public and private debt the central bank is unable to change its monetary policy stance ad-hoc, due to the costs caused by the inverse relationship between interest rates and stock prices.

The most well-known programs of this type are the quantitative easing programs carried out by the Fed. After their deployment, the US central bank's balance sheet developed as it can be seen in the chart below:

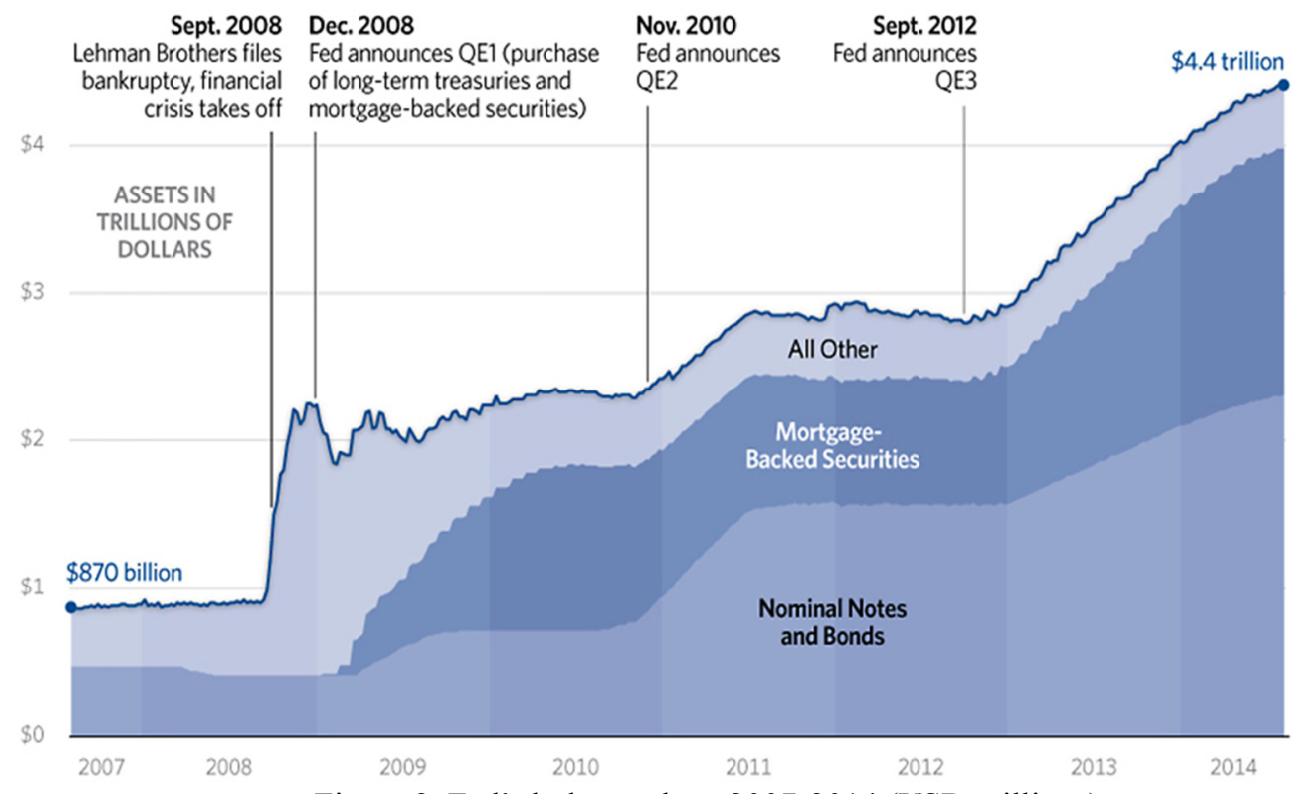

Figure 2. Fed's balance sheet 2007-2014 (USD millions)

Source: www.heritage.org.

In the first program, launched in December 2008, the Fed announced it would buy securities issued by the two state companies in the amount of USD 100 billion and mortgage-backed securities worth of USD 600 billion. In the second program, in November 2010, the Fed announced that it would buy long-term government bonds worth of USD 600 billion at a rate of USD 75 billion per month. In the third program, which began in September 2012 and ended in October 2014, the Fed bought stocks worth of USD 45-85 billion per month.

Regarding the European Central Bank (ECB), given that the euro zone borrows money predominantly through the banking sector, it has provided unlimited liquidity to commercial banks, if they had quality collateral. Subsequently, this list of eligible collateral has been enlarged.

When these measures proved to be insufficient, the ECB launched the Securities Markets Programme by which it started to buy government bonds directly from secondary markets. These were held until they reached maturity and the liquidity created through these purchases was sterilized. This program was replaced with the Outright Monetary Transactions (OMT) program, through which the ECB committed to buy short-term bonds on 
secondary markets in unlimited quantities in order to support the Eurozone countries that risked abandoning the euro. The access is conditioned by four criteria: the applicant must have received help through the Eurozone bailout funds, the European Financial Stability Facility / European Stability Mechanism, it must have respected those assumed in the Memorandums of Understanding signed on the receipt of those funds, it must have access to financial markets and, if all of these are met, the acquisition of securities through the OMT would begin only if the interest rate demanded on that countries bonds is inconsistent with its economic status. At the time of this writing, no state had asked for support through this program, but its existence seems to have calmed markets for government securities. As for the ECB balance sheet, its evolution is captured in the figure below.

Main refinancing operations

Covered-bond programs

Government bond buying program (2010- '12)

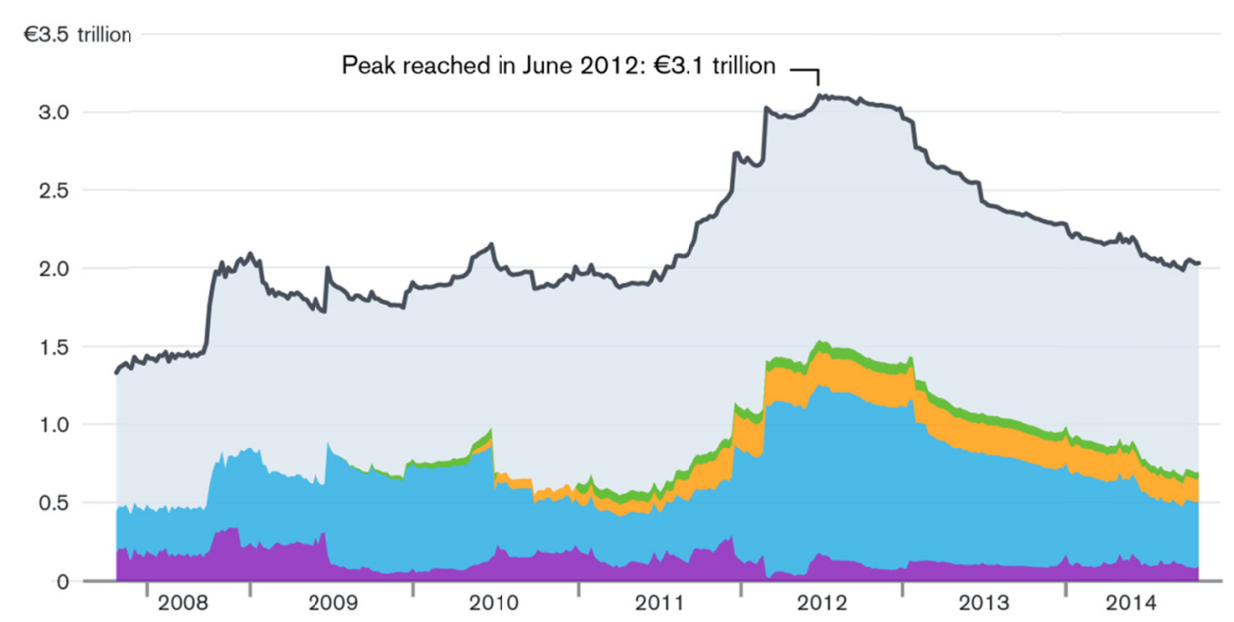

Figure 3. ECB balance sheet evolution (EUR billions)
Long-term loans to banks

Remaining assets

Source: Bloomberg.

Regarding the efficiency of these operations, it is difficult to give an answer now. The general consensus is that they had an effect, but it is unclear how strong. As in other situations, such as using the changings the price index as benchmark for inflation, the problem lies in accurately identifying which of these effects were caused by these monetary operations and which were caused by other factors. On the other hand, the fact that these operations continued for a long period of time or are still continuing indicates that their outcome was, so far, not the desired one. Most of the excess liquidity created by these programs remained in the reserves of commercial banks, for the reason that they have not found lending opportunities. In contrast, the central banks' balance sheet ended up containing a huge amount of so-called toxic assets, thus clearing the balance sheet of commercial banks. In other words, these assets were exchanged for money issued by central banks, practically bailing-out the banks.

In terms of efficiency, the only experience of quantitative easing that can be investigated empirically, the one that Bank of Japan conducted during 2001-2006, does not provide clear conclusions. Some studies conclude that the measures taken by the Japanese central bank appears to have had some effectiveness, but only in the sense of a slight decrease in long-term interest rates. Others see it beneficial as it maintained the financial markets' stability, but in terms of stimulating economic activity the effects were small and uncertain. From the governments' point of view, these programs led to a reduction in the costs with interests paid, as previously stated. Moreover, the government is the shareholder who enjoys most of the profits made by the central bank as a result of currency issuance through the consistent taxation of its profit. For example, in the case of Romania, 80\% of the profit made by the National Bank is paid as tax. In the US, after the central bank shareholders (which are private) receive an annual dividend of $6 \%$, the remaining profit goes to the treasury.

\section{Conclusions}

Commodity money was the first rule limiting the money issuance, i.e. the convertibility rule. Experience has shown, however, that this rule is not sufficient to ensure price stability by itself, since keeping fractional reserves 
without stipulating a minimum required level for them meant that the amount of money was practically indefinite. This type of money began to lose its importance in the early twentieth century, as the perception migrated from exchange rate stability to price stability. Under this new vision, the Bretton Woods regime was implemented, with the hope of promoting prosperity i.e. full employment and rising wages. The system was flawed by was became to be known as the "Triffin dilemma", because the US pursued an inflationary policy which was in line with its domestic goals but not appropriate with its role as supplier of the reserve currency. This shows that a system which depends on a single reserve currency is not the best choice, as its supplier might be interested in pursuing primarily its own economic objectives or tempted to gain extra advantages, which will eventually undermine the system.

The move from commodity money to fiat money and the loss of the opportunity to convert the latter into something of value generated the problem of ensuring their credibility. In this sense, there were tried several alternatives, from targeting the exchange rate, the monetary aggregates and, eventually, inflation. Empirical research has shown that all these monetary regimes have drawbacks, mainly due to the inflexibility imposed by the rules. Consequently, guiding monetary policy according to strict rules is not the optimal approach.

The late twentieth and early twenty-first century were characterized by a relaxation of the regulations, which caused in 2008 one of the worst economic crisis. In response, the authorities' actions have taken a strong discretionary approach by launching quantitative easing programs (America) and intervening to defend the currency (the Eurozone). Since the effectiveness of these policies is questionable and long-term effects (especially the redistribution of wealth) and how to abandon them are still unknown, it is clear that a purely discretionary approach is not desirable either.

Therefore, future actions will probably be to implement a more restrictive framework for the discretionary component of the authorities' decision. A starting point might be to increase transparency regarding, for example, how the central bank sets the policy rate or decides to increase the monetary base. Moreover, for the banks managing reserve currencies and other major central banks (such as those of China, Japan and England) could be established public rules governing the money issuance and the policy rate. Furthermore, such measures must be combined with improving the enforced regulations, so attention should also be geared towards the micro level, where most important is to maintain financial stability. Last, but not least, it is important to remember that this stability should come as a result of the improvement of the general welfare, as the architects of the old Bretton Woods system envisioned.

\section{Acknowledgements}

This work was co-financed from the European Social Fund through Sectorial Operational Programme Human Resources Development 2007-2013, project number POSDRU/159/1.5/S/142115. Performance and excellence in doctoral and postdoctoral research in Romanian economics science domain".

\section{References}

Asso, F., Kahn, G., \& Leeson, R. (2007). Monetary Policy Rules: From Adam Smith to John Taylor. Paper presented at the Taylor Rule conference, Dallas, TX. Retrieved from http://www.dallasfed.org/assets/documents/research/events/2007/07taylor_leeson.pdf

Asso, F., Kahn, G., \& Leeson, R. (2010). The Taylor rule and the practice of central banking. The Federal Reserve Bank of Kanssas City Research Papers, 10-05. Retrieved from http://www.kc.frb.org/PUBLICAT/RESWKPAP/PDF/rwp10-05.pdf

Badescu, B. (2013). Free Banking: Some Empirical Findings. Valahian Journal of Economic Studies, 4(18), 7-14. Retrieved from http://www.vjes.eu/images/2013/issue4/vjes\%20vol.\%204\%2018\%20issue\%204\%202013\%20-\%20bogdan $\% 20$ badescu.pdf

Bagehot, W. (1873). Lombard Street: A description of the Money Market. Retrieved from https://archive.org/details/lombardstreetad00bagegoog

Bernanke, B. (2012). The Federal Reserve and the Financial Crisis. Origins and Mission of the Federal Reserve speech at George Washington University, Washington, 2012.

Bordo, M. (1993). The Bretton Woods International Monetary System: A Historical Overview. In M. D. Bordo \& B. Eichengreen (Eds.), A Retrospective on the Bretton Woods System: Lessons for International Monetary Reform (pp. 3-108). Chicago: University of Chicago Press. http://dx.doi.org/10.7208/chicago/9780226066905.001.0001 
Bowdler, C., \& Radia, A. (2012). Unconventional monetary policy: The assessment. Oxford Review of Economic Policy, 28, 603-621. http://dx.doi.org/10.1093/oxrep/grs037

Cerna, S. (2014). Politica monetară neconvențională. Centrul pentru Economie \& Libertate. Retrieved from http://www.ecol.ro/content/politica-monetara-neconven\%C8\%9Bionala

Fischer, I. (1920). 100\% money. Retrieved from http://fisher-100money.blogspot.ro/

Jastram, R., \& Leyland, J. (1977). The Golden Constant. Cheltenham, U.K: Edward Elgar Publishing Limited.

Keynes, J. M. (1923). A tract on monetary reform. Retrieved from http://delong.typepad.com/keynes-1923-a-tract-on-monetary-reform.pdf

Mafi, E. (2003). The Relationship between Currency Competition and Inflation. Kyklos, 56(4), 475-490. http://dx.doi.org/10.1046/j.0023-5962.2003.00234.x

Meltzer, A., \& Robinson, S. (1989). Stability under the Gold Standard in Practice. National Bureau of Economic Research, 163-202.

Mishkin, F. (1999). International Experience with different monetary policy regimes. NBER Working Paper, 19448. http://dx.doi.org/10.3386/w6965

Smith, A. (2005). An inquiry into the nature and causes of the wealth of nations. An Electronic Classics Series Publication, The Pennsylvania State University. Retrieved from: http://www2.hn.psu.edu/faculty/jmanis/adam-smith/wealth-nations.pdf

Taylor, J. (1993). Discretion versus policy rules in practice. Paper presented at the Carnegie-Rochester Conferences Series on Public policies, 39, 195-241. http://dx.doi.org/10.1016/0167-2231(93)90009-L

Thornton, H. (1802). An Inquiry into the nature and effects of the paper credit of Great Britain. Retrieved from https://mises.org/sites/default/files/An $\% 20$ Enquiry $\% 20$ into $\% 20$ the $\% 20$ Nature $\% 20$ and $\% 20$ Effects $\% 20$ of $\% 2$ 0the $\% 20$ Paper\%20Credit $\% 20$ of $\% 20$ Great $\% 20$ Britain_3.pdf

Various press releases of the European Central Bank.

Various press releases of the Federal Reserve Bank.

Volckart, O. (2007). Rules, Discretion or Reputation? Monetary Policies and the Efficiency of Financial Markets in Germany, 14th to 16th Centuries. SFB 649 Discussion Paper, 2007-007. Retrieved from http://sfb649.wiwi.hu-berlin.de/papers/pdf/SFB649DP2007-007.pdf

\section{Copyrights}

Copyright for this article is retained by the author(s), with first publication rights granted to the journal.

This is an open-access article distributed under the terms and conditions of the Creative Commons Attribution license (http://creativecommons.org/licenses/by/3.0/). 